benefits of new technologies including the use of genetically 'engineered' organisms.

Advances in Ecology investigates the recent advances made in the understanding of basic population biology of interacting species and the ways in which this underpins the structure of ecological communities. The implications of these developments are pervasive - ranging from the development of harvesting strategies to designing Nature reserves, planning vaccination strategies, and controlling pests. They are important in our gaining a much improved understanding of the consequences of changing agricultural practices - partly driven by European Community considerations - which make the problems of habitat restoration, and of controlling weeds and other pests and infectious diseases, all potentially more serious. The effects of aerial pollutants, such as ozone and carbon dioxide, on plant and animal populations, and the dynamics of ecological succession with particular reference to habitat restoration following changes in agricultural practices, are also of considerable importance.
From another perspective, triumphs of intensive agriculture have been accompanied by progressive narrowing of the genetic diversity of the plants exploited. The likelihood of global changes in climate gives fresh emphasis to the desirability of conserving existing gene-pools and investigating the possibility of utilizing new plants. There is thus an urgent need to understand the structure and functioning of ecosystems, and the processes that maintain biodiversity.

Course participants are provided with a thorough grounding in the fundamental principles of population and community ecology, and how these principles relate to applied disciplines. The course in 1996 will last from 7 to 24 May.

T.H. JONES, Course Coordinator
NERC Centre for Population Biology
Imperial College at Silwood Park
Ascot
Berkshire SL5 $7 P Y$
England, UK.

\title{
Population Action International (PAI)
}

$\mathrm{T}$ his is a Washington DC-based, non-profit, nongovernmental organization that was founded in 1965 as the Population Crisis Committee. Population Action International is committed to universal access to voluntary family planning and reproductive health services, reproductive choices for women as well as men, and early stabilization of world population at a lastingly supportable level.

Recognized for its expertise on international family planning and population issues, Population Action International carries out its mission through the broad dissemination of policy-oriented educational materials to policymakers, the media, and the general public. PAI works to develop and strengthen the commitment of governments to increased financial assistance for high-quality, voluntary family planning and related programmes especially in developing countries.

The work of PAI, carried out by a staff of 40 people under the guidance of a distinguished and actively involved Board of Directors, focuses on four programmatic areas: policy research and analysis, political affairs, population and environment, and special projects.

PAI's policy research and analysis staff produces materials for use by policymakers, health personnel, and the general public. The materials include an annual Report Card ranking more than 100 countries on key socio-economic indicators, critiques of donor agency population assistance programmes, in-depth country studies of family planning and population programmes, and information kits on family planning and reproductive health-care issues.

PAI's political affairs department is responsible for liaison with the US Congress and Administration, as well as with the United Nations and other international agencies on the development and implementation of international population and family planning policies. The political affairs staff work directly with government officials and in coalition with other nongovernmental organizations.

In 1992, PAI formally established a population and environment programme to examine the impact of population growth and consumption patterns on such critical resources as fresh water, arable land, and the global atmosphere. Through publications examining these linkages, programme staff work to promote the concept of 'sustainable development'.

The Special Projects Fund (SPF) provides private money for ground-breaking initiatives in the reproductive health and family planning field. Projects supported by SPF in 1992-93 included research on the relationship between women's economic empowerment and reproductive behaviour; research and training in the treatment of septic and incomplete abortion; and demonstration projects to improve adolescent access to family planning information and services. For more than a decade, SPF has also collaborated with African leaders and activists to eradicate harmful traditional practices, with a special focus on female genital mutilation.

Patricia M. Sears, Deputy Director Population Action International 112019 th Street, NW, Suite 550 Washington

DC 20036

USA. 